\title{
Аналіз парку військової автомобільної техніки, яка потребуватиме відновлення рухомими засобами технічного обслуговування та ремонту
}

\author{
Володимир Дачковський ${ }^{*}$; Irop Кондратюк ${ }^{\text {A }}$ \\ А Національний університет оборони України імені Івана Черняховського, пр-кт Повітрофлотський, 28, г. Київ, 03049, Україна
}

Received: December 15, 2020 | Revised: December 25, 2020 | Accepted: December 31, 2020

DOI: $10.33445 /$ sds.2020.10.6.20

\begin{abstract}
Анотація
У статті проведено аналіз парку військової автомобільної техніки, яка знаходиться на озброєнні військових частин (підрозділів) Збройних Сил України, яка потребуватиме технічного обслуговування та ремонту рухомими засобами технічно обслуговування та ремонту в польових умовах під час ведення бойових дій. Проведений аналіз військової автомобільної техніки свідчить, що більшість новітніх зразків, які знаходяться на озброєнні у військових частинах (підрозділах) Збройних Сил України перебувають на гарантійному терміні експлуатації від виробника, який підходить до завершення або уже завершився. За результатами аналізу встановлено, що більшість зразків автомобільної техніки оснащені новітніми базовими шасі закордонних виробників, дизельними двигунами екологічного класу Євро IV, сучасними системами забезпечення, електроустаткуванням та контрольновимірювальними приладами нового покоління. Разом з цим, проведений аналіз основних несправностей новітніх зразків військової автомобільної техніки показав, що зразки військової автомобільної техніки в основному виходили з ладу через низьку якість окремих деталей та складових одиниць, незадовільний стан сировини або порушення технологічного процесу тощо. Крім того, враховуючи потребу в проведенні технічного обслуговування та ремонту військової автомобільної техніки визначено невідповідності у можливостях існуючих на озброєнні рухомих засобів відновлення. Визначено, що в основі формування рухомих засобів технічного обслуговування та ремонту з урахуванням завдань, які покладаються на ремонтновідновлювальні підрозділи повинні лежати три основних принципи: базовий, який полягає в розробленні уніфікованої базової платформи; мобільний, який полягає у забезпеченні можливості транспортування різними видами транспорту; блочно-модульний, який полягає у комплектуванні сучасними засобами діагностики та спеціальним обладнанням для виконання специфічних завдань з технічного обслуговування та ремонту військової автомобільної техніки на різних рівнях ієрархії.
\end{abstract}

Ключові слова: військова автомобільна техніка, рухомі засоби технічного обслуговування та ремонту, відновлення, технічне обслуговування і ремонт.

\section{Постановка проблеми}

Застосування військової автомобільної техніки (ВАТ) військами (силами) збільшує темпи пересування військ та забезпечує їх мобільність. Аналіз виконання завдань військовими частинами (підрозділами) на території Донецької та Луганської областей виявив низку проблемних питань, пов'язаних з відновленням ВАТ.
Важливу роль при цьому відіграє ВАТ, яка широко застосовуються під час транспортування озброєння та військової техніки (ОВТ), перевезення особового складу та військово-технічних вантажів, тощо. Тому від рівня технічної готовності ВАТ залежить і рівень бойової готовності військ.

\footnotetext{
* Corresponding author: к.т.н., доцент, доцент кафедри, e-mail: 1903vova@ukr.net, ORCID: 0000-0003-1480-5021
} 
Застосування військових частин в умовах сьогодення обумовлені новими умовами ведення збройної боротьби та широким застосуванням нових та модернізованих систем озброєння. 3 початком агресії Російської Федерації проти України на озброєнні ЗС України існуючий парк, складався із зразків ВАТ, які були спроектовані ще в 70-х роках для потреб Радянської Армії. Головним недоліком якої $\epsilon$, фізичне і моральне старіння.

У зв'язку з цим для виконання завдань 3С України розпочали інтенсивну закупівлю в провідних українських компаніях вітчизняного оборонно-промислового комплексу (ОПК) новітніх зразків ВАТ для переозброєння військових частин (підрозділів), яка відповідає сучасним умовам, з гарантійними термінами експлуатації від виробника та проведенням технічного обслуговування i ремонту (TO і P).

Необхідно зауважити, що у разі виходу з ладу новітніх зразків ВАТ після закінчення їх гарантійного терміну, важливе значення має приведення їх до працездатного стану в мінімально короткі терміни за допомогою рухомих засобів технічного обслуговування i ремонту (РЗТО і Р), в польових умовах.

Разом з цим, інтенсивний розвиток військової автомобільної техніки висуває підвищені вимоги до РЗТО і Р військової автомобільної техніки під час бойових дій у локальних війнах та збройних конфліктах. Необхідно розуміти, що закупівля однієї номенклатури ВАТ тягне за собою потребу у створенні в ЗС України ремонтних комплектів для ремонтно-відновлювальних підрозділів (військових частин) різного рівня ієрархії, які будуть обслуговувати та ремонтувати даний зразок ВАТ. Крім того немаловажним $€$ той факт, що при закупівлі новітньої ВАТ необхідно враховувати норми завантаження вантажних платформ відповідними матеріальними засобами, ракетами та боєприпасами, тощо. Дані платформи повинні відповідати встановленим стандартам щоб не виникали такі ситуації при яких вантажопід'ємність ВАТ дозволяє підняти відповідні матеріальні засоби але немає змоги їх розмістити на вантажній платформі. Відповідно на даний час виникають невідповідності між можливостями ремонтних підрозділів на озброєнні, яких знаходяться морально та фізично застарілі РЗТО і Р та потребами у ТО і ремонті нових зразків ВАТ, прийнятих на озброєння за останні роки в яких завершився термін гарантійної експлуатації. Відсутність в обладнанні РЗТО і Р засобів діагностики, сучасних засобів зв'язку, інструменту та спеціальних приладів, які призначені для ремонту прийнятих за останні роки на озброєння ВАТ, знижують виробничі можливості ремонтних підрозділів (військових частин) а інколи взагалі унеможливлюють повернути до строю ВАТ, яка потребує ТО або ремонту.

\section{Аналіз останніх досліджень та публікацій}

Дослідженню питань щодо розвитку ВАТ присвячена ціла низка робіт, зокрема в роботі [1] розглянуто сучасний стан парку автомобілів та військової автомобільної техніки ЗС України. Де з аналізу тенденцій розвитку ВАТ в арміях НАТО визначено необхідність оновлення застарілого парку автомобілів 3С України та сформовано перспективний типаж повнопривідної ВАТ та агрегатно уніфікованих бойових і спеціальних колісних машин з врахуванням потенціалу вітчизняного машинобудування та критичного імпорту агрегатів і вузлів. Так, в роботі [2] на основі проведеного аналізу застосування військових частин Сухопутних військ у ООС (АТО), з урахуванням практичного досвіду, набутого військами у ході проведення ООС (АТО) розроблені пропозиції та визначені напрями щодо удосконалення ВАТ. У роботах [3-5] розглянуті зразки броньованих машин провідних країн світу, але в даній роботі не 
розглядаються основні напрямки їх розвитку. У роботі [6] проведений аналіз бойових броньованих машин, які запропоновані вітчизняним ОПК України. На його основі визначені основні тенденції щодо їх розвитку. В роботі [7] розглянуто науково-методичний апарат щодо обгрунтування вимог на розроблення зразків ОВТ та спеціальної техніки, а у роботі [8] наведено методичні аспекти комплексної оцінки експлуатаційнотехнічних властивостей зразків ОВТ. Робота [9] стосується аналізу шляхів розвитку рухомих засобів ремонту ОВТ. В ній проаналізовані рухомі засоби ремонту, розроблені військово-промисловим комплексом Білорусії та Російської Федерації В основі яких покладено застосування системи "мультиліфт", а робота [10] присвячена методичним підходам щодо формування тактико-технічних вимог до технічних засобів відновлення ОВТ, що дозволяє обґрунтувати тенденції розвитку та принципи будови рухомих засобів технічного обслуговування i ремонту ОВТ. Але не враховано, що на різних рівнях ієрархії обсяг завдань з ремонту ОВТ буде відрізнятись тим самим використання однотипних рухомих засобів ремонту ОВТ $\epsilon$ економічно недоцільним. В роботі [11] проведений аналізу спроможностей вітчизняних підприємств щодо розробки та виробництва сучасних рухомих ремонтних майстерень військової автомобільної техніки, а в роботі [12] розглянуто напрямки розвитку та основні конструктивні особливості бойових броньованих машин типу MRAP, які змонтовані на автомобільних платформах. Найбільш доцільний варіант побудови автомобільних платформ відображено у публікаціях [13, 14] суть яких полягає у розробленні однотипних гусеничних та колісних платформ побудованих за модульним принципом. Також передбачається їх розподілити на три класи важкі, середні та легкі та в подальшому в залежності від потреби військ встановлювати на дані платформи відповідні модулі озброєння, вантажні модулі, модулі засобів ремонту, тощо.

\section{Постановка завдання}

Тому враховуючи результати попередніх досліджень, існує необхідність в проведені аналізу парку новітніх зразків ВАТ, які поступили на озброєння ЗС України та, які потребуватимуть відновлення рухомими засобами технічно обслуговування та ремонту, визначити переваги та недоліки, та сформувати напрямки подальшого їх розвитку, що і буде метою даної статті.

\section{Виклад основного матеріалу}

Аналіз парку ВАТ ЗС України свідчить, що з 2014 року до цього часу на доукомплектування військових частин (підрозділів) поступають нові зразки ВАТ, які становлять понад 2900 од. Дані зразки ВАТ знаходяться на озброєні військових частин ЗС України та перебувають на гарантійному терміні експлуатації від виробника, який підходить до завершення або уже завершився.

Так, на початок ведення бойових дій Україна отримала від уряду США в якості міжнародної технічної допомоги близько 203 од. автомобілів підвищеної прохідності
HMMWV - легко броньований автомобіль "Hummer"(the High Mobility Multipurpose Wheeled Vehicle - високомобільний багатоцільовий колісний транспортний засіб) 3 колісною формулою $4 \times 4(4 \times 4)$, які здатні витримувати обстріл 3 автоматичної зброї. Оснащені дизельним двигуном V8 GM 6.2L потужністю 160 к.с., або V8 GM 6.5L потужністю до 195 к.С., автоматичною чотири діапазонною КПП GM 4L80-E, 3 двоступеневою роздавальної коробкою передач. Максимальна швидкість 113 км/год [15]. В цілому автомобілі HMMWV показали 
достатню надійність та прохідність при виконанні бойових завдань підрозділами десантно-штурмових військ, морської піхоти на озброєнні яких вони перебувають.

Вітчизняним виробником ПАТ “АвтоКрАЗ" було розроблено та поставлено для ЗС України новітні зразки ВАТ сімейства КрАЗ понад 1400 од. із яких вантажні автомобілі багатоцільового призначення та броньовані автомобілі спеціального призначення, такі, як:

вантажний КрАЗ-6322 з колісною формулою (6х6), вантажопідйомністю 12000 кг, близько 550 од. та КрАЗ-5233ВЕ (4х4), вантажопідйомністю 6000 кг, підвищеної прохідності, близько 500 од. Дані автомобілі призначені для оперативної доставки особового складу військових підрозділів дорогами 3 різноманітним покриттям, бездоріжжю та пересіченій місцевості. Також дані автомобілі використовуються для встановлення різного устаткування, буксирування причепів і різних причіпних систем в екстремальних природних кліматичних умовах. Максимальна швидкістю 80-85 км/год [16]. Оснащені сучасними системами забезпечення автомобіля, дизельним двигуном ЯМЗ, Cummins, Deutz V-подібним, восьми циліндровим, 3 газотурбінним наддувом 3 потужністю 243 (330) к.с., восьми ступінчастою механічною двухдіапазонною КПП;

сідельний повнопривідний автотягач КрА3-6446 (6х6) [16], понад 160 од. зразків знаходяться на озброєні ремонтних підрозділів, 3 напівпричепом сімейства "ВАР3", понад 200 од. від вітчизняного виробника ООО "ВАРЗ" (Верхньодніпровський авторемонтний завод) [17], ВАРЗ НПК 4012, ВАР3 НПВ-6009 вантажопідйомністю 50000-60000 кг. КрАЗ-6446 призначений для транспортування всіх видів ОВТ в сцепі $з$ напівпричепом і експлуатації дорогами усіх категорій, і бездоріжжю 3 вертикальним навантаженням на сідельнозчіпний пристрій 16600-17000 кг. Максимальна швидкістю 85 км/год. Оснащений сучасними системами забезпечення автомобіля, а саме дизельним двигуном яМ3, Cummins, Deutz V-подібним, восьмициліндровим, 3 газотурбінним наддувом, потужністю 330 (370) к.с. та двухдіапазонною, восьми ступінчастою дев' яти ступінчастою механічною КПП;

броньований автомобіль КрАЗ "SPARTANAPC" $(4 \times 4)$ [16], - близько 30 од. знаходяться на озброєні підрозділів ЗС України. Призначений для перевезення особового складу, транспортування зразків озброєння, військових вантажів і майна по всіх видах доріг, проведення спеціальних операцій, таких, як розвідка, патрулювання, супровід транспортних засобів при виконанні спеціальних завдань, передача розпоряджень та забезпечення зв'язку, вогневої підтримки особового складу, а також для захисту екіпажу та особового складу, що транспортується від вогню стрілецької зброї, осколків і мін. Максимальна швидкістю 110 км/год. Оснащений сучасними системами забезпечення автомобіля, базовим шасі Ford 550, дизельним двигуном Ford 6,7 ТД V8 3 потужністю 400 к.с., автоматичною шестишвидкісною КПП.

Також, вітчизняним виробником - Дочірнім підприємством “Автоскладальний завод №2" Публічного акціонерного товариства “Автомобільна Компанія “Богдан Моторс" було розроблено та поставлено для ЗС України новітні зразки ВАТ сімейства БОГДАН понад 1200 од. вантажних автомобілі багатоцільового призначення та легкових автомобілів спеціального призначення, такі, як:

вантажний БОГДАН (МАЗ) 6317 (БОГДАН 6317WP - 3 двигуном WeichalPower) (6x6) вантажопідйомністю 11000 кг, підвищеної прохідності, близько 900 од. знаходяться на озброєні підрозділів (військових частин), БОГДАН 5316 (МАЗ) (4x4) вантажопідйомністю 6000 кг, підвищеної прохідності, понад 100 од.. Призначені дані автомобілі для оперативної доставки особового складу військових підрозділів по дорогам із різноманітним покриттям, бездоріжжю та 


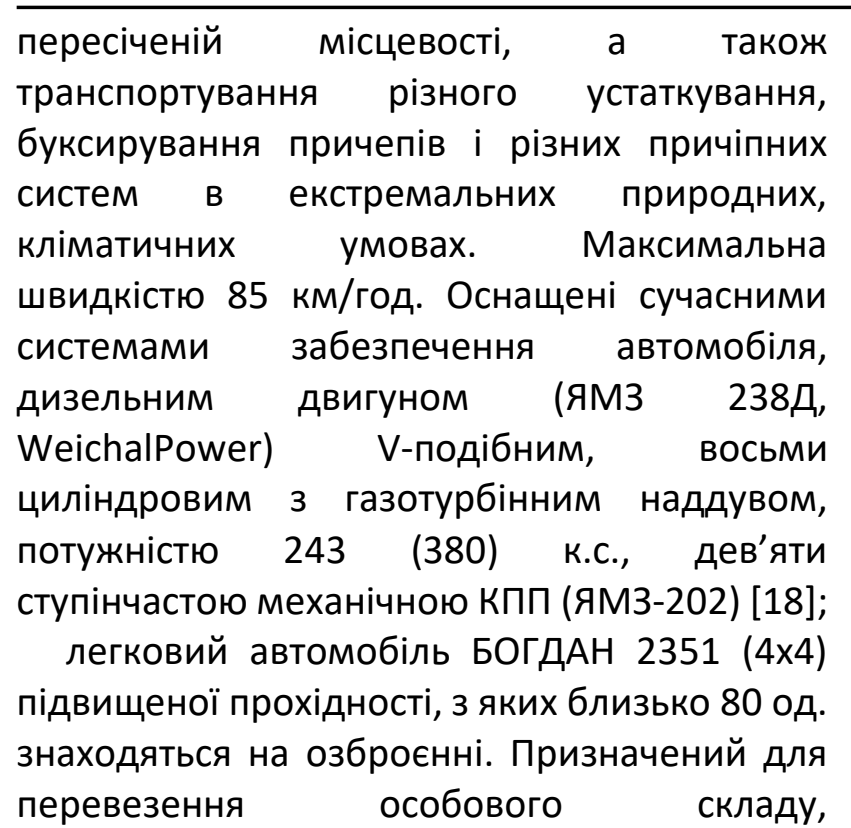
транспортування невеликих вантажів і майна по всіх видах доріг, проведення спеціальних операцій (дій), таких як патрулювання, супровід транспортних засобів при виконанні спеціальних завдань. Максимальна швидкість 130 км/год. Оснащений базовим шасі Great Wall Wingle 5 doublecab, дизельним двигуном, 3 турбонаддувом моделі GW4D20, потужністю 105 (143) к.с., екологічного класу Євро IV. Обладнаний сучасними системами забезпечення, гальмівною системою, електроустаткуванням контрольно-вимірювальними приладами, шести ступінчастою механічною КПП [18].

Ще одним, вітчизняним виробником ВАТ $\epsilon$ ПрАТ “Науково-виробниче об'єднання “Практика", яким було розроблено та поставлено для 3С України близько 130 од. спеціалізованих броньованих автомобілів, таких, як:

броньований автомобіль “КОЗАК-2 (2М)" (4х4) підвищеної прохідності, близько 120 од., які знаходяться на озброєні військових частин (підрозділів). Призначений для транспортування особового складу десантноштурмових військ, сил спеціальних операцій, морської піхоти ЗС України та їх вогневої підтримки в бою незалежно від пори року, при експлуатації на дорогах загального користування та в умовах бездоріжжя. Може забезпечувати автономні, мобільні дії у складі обмежених тактичних груп протягом 3$x$ діб незалежно від кліматичних, метеорологічних умов у будь-який час доби. Максимальна швидкість 120 км/год. Оснащений сучасними системами забезпечення автомобіля, базовим шасі IVECO EUROCARGO, однорядним шести циліндровим дизельним двигуном, 3 турбонаддувом Iveco Tector, потужністю 205 (279) к.с., екологічного класу Євро IV, шестиступінчастою механічною КПП (ZF 6S800) [19];

броньований вантажний автомобіль на шасі Богдан (МА3)-631724WP (6x6) підвищеної прохідності (компанії “Богдан Моторс") 3 системою самозавантаження “Мультиліфт" (Hiab Multilift), вантажопідйомністю 11600 кг, підвищеної прохідності, близько 9 од. знаходяться на озброєні військових частин (підрозділів). Призначений для перевезення боєприпасів на шасі автомобіля з мультиліфтом, монтажу обладнання самонавантаження - саморозвантаження різного устаткування, а також захисту від куль, уламків мін і снарядів, особового складу, що розміщується в кабіні автомобіля. Крім перевезення боєприпасів, автомобіль може використовуватись для транспортування спеціального обладнання та вантажів, а також використовується, як евакуатор пошкодженої техніки. Максимальна швидкістю 85 км/год. Оснащений сучасними системами забезпечення автомобіля, дизельним двигуном ЯМ3 238Д, WeichalPower, Vподібним восьмициліндровим 3 газотурбінним наддувом, потужністю 243 (380) к.с., восьми - дев'ятиступінчастою механічною КПП (яМЗ-202, 239) [20].

Ще одним альтернативним вітчизняним виробником Конструкторсько-виробничим підприємством “Українська бронетехніка" було розроблено та поставлено для ЗС України понад 120 од. спеціалізованих броньованих автомобілів, таких, як:

спеціальний броньований автомобіль “ВАРТА" (4x4) підвищеної прохідності, понад 
80 од. Призначений для перевезення особового складу, транспортування зразків озброєння, військових вантажів і майна по всіх видах доріг, проведення спеціальних операцій, таких як розвідка, патрулювання, супровід транспортних засобів при виконанні спеціальних завдань, передача розпоряджень та забезпечення зв'язку, вогневої підтримки особового складу, а також для захисту екіпажу та особового складу, який транспортується від вогню стрілецької зброї, осколків і мін. Максимальна швидкість 100 км/год. Оснащений сучасними системами забезпечення автомобіля, системою пожежогасіння моторного та десантного відсіку, автономною кліматичною системою, спеціалізованим двовісним шасі високої прохідності та спеціальними амортизаторами двосторонньої дії, дизельним шистициліндровим двигуном, V-подібним 3 турбонаддувом, 3 потужністю 380 к.с, паливною апаратурою Common Rail ЯM365651, девятиступінчастою механічною КПП яМ3-2381-06, 3 дводіапазонним планетарним демультиплікатором [21];

броньований автомобіль “НОВАТОР” (4x4) підвищеної прохідності, близько 40 од. знаходяться на озброєнні. Призначений для перевезення особового складу, транспортування зразків озброєння, військових вантажів і майна по всіх видах доріг, проведення спеціальних операцій, таких як розвідка, патрулювання, супровід транспортних засобів при виконанні спеціальних завдань. Максимальна швидкість до 140 км/год. Оснащений сучасними системами забезпечення автомобіля, системою пожежогасіння моторного та десантного відсіку, автономною кліматичною систему, системою навігації та системою Run-flat, яка дозволяє продовжувати рух навіть при пошкодженні коліс, базовим шасі Ford F-550, дизельним двигуном Ford 6,7 ТД V8 з потужністю 400 к.с, шестиступінчастою автоматичною КПП Runflat Inserts [21].
Проведений аналіз застосування зазначених зразків ВАТ у військових частинах 3С України в цілому підтверджує відповідність їх тактико-технічних характеристик потребам військ. Автомобілі задовольняють визначеним вимогам та забезпечують виконання військовими частинами ЗС України завдань за призначенням, але, поряд з цим проведений аналіз показав ряд проблемних питань, які потребують вирішення щодо покращення конструктивних та тактико-технічних характеристик автомобілів.

Так, за час їх використання в гарантійний термін зафіксовано близько 4345 випадків поломок (несправностей). Основними причинами несправностей були низька якість окремих деталей та складових автомобіля 26\%; незадовільний стан сировини або порушення технологічного процесу виготовлення - 29\%; недостатній рівень знань у особового складу водіїв будови та правил експлуатації закріплених автомобілів - 20\%; інші - 25\%. Що стосується конструктивних особливостей, а саме ВАТ підвищеного рівня захищеності то головним недоліком $€$ їі габаритні розміри а саме, висота, яка становить понад 3 м. Крім того, усі зразки BAT, які були закуплені 3С України та поступили на укомплектування військових частин відносяться до важкої категорії ВАТ а потреба також існує у середній та легкій категорії ВАТ.

Також під час експлуатації зазначеної ВАТ виникають проблемні питання, а саме: складність в проведенні технічного обслуговування і ремонту (ТО і Р); непристосованість до ремонту в польових умовах за допомогою існуючих на озброєнні ЗС України РЗТО та Р; відсутність запасних частин та відповідних експлуатаційних матеріалів; відсутність технічної документації для проведення ТО і Р; відсутність навчених спеціалістів з обслуговування та ремонту новітньої ВАТ.

Світовий досвід засвідчує, що в ході розробки новітніх та модернізації існуючих 
зразків ВАТ основними критеріями $\epsilon$ : захищеність та маневреність зразка ВАТ, уніфікація, ремонтопридатність, відновлюваність, тощо [22]. Відповідно і засоби технічного обслуговування та технічної діагностики ВАТ повинні мати необхідні прилади для перевірки параметрів ВАТ [23].

Так, на прикладі броньованих автофургонів КрАЗ-SPARTAN-APC, КОЗАК-2, BAPTA, НОВАТОР, які вже прийняті на озброєння ЗС України, у ремонтно відновлювальних підрозділах відсутні контрольно-перевірочні машини для перевірки систем забезпечення автомобілів та їх діагностики.

Для контролю тактико-технічних характеристик зразків ВАТ та підтримання їх в боєздатному стані, новітні зразки ВАТ мають елементи комп'ютеризації та роботизації комплексів, системи навігації, зв'язку та діагностики, які необхідно діагностувати та проводити перевірку технічного стану.

Одночасно в ході оснащення збройних сил провідних країн світу новітніми та модернізованими зразками ВАТ, розробляються машини технічного обслуговування та ремонту 3 новітніми пристроями для технічної діагностики. Прикладом цих країн є: ФРН, США, Франція, тощо. Крім цього на базі нових та модернізованих зразків ВАТ розробляються засоби евакуації та ремонту, з елементами та приладами для діагностування ВАТ. Нажаль на рухомих засобах відновлення ВАТ, які знаходяться на озброєнні ЗС України - це не передбачено. Провідні країн світу переходять на уніфіковані контрольно-перевірочні машини нового покоління, які здатні проводити технічну діагностику зразків ВАТ.

Зростання ролі і значення технічної діагностики ВАТ також пов' язане із загальним технічним розвитком і ускладненням ВАТ та з необхідністю забезпечення технічної та екологічної безпеки та ефективністю експлуатації ВАТ [24].

При глобалізації методів і засобів технічного контролю і діагностики

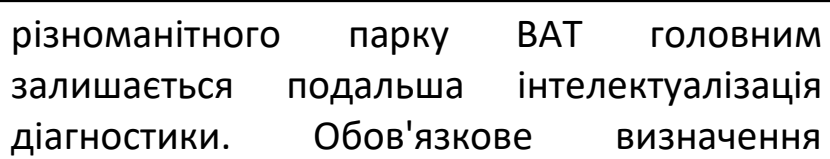

залишкового ресурсу в реальному часі, зниження ризиків експлуатації та мінімізація впливу особового складу для обслуговування ВАТ на прийняття кінцевого рішення. Такі завдання вимагають істотного підвищення рівня діагностичного забезпечення ВАТ i відповідно рівня професійної підготовки фахівців-ремонтників 3 діагностики таких зразків ВАТ. Важливу роль у формуванні кваліфікації фахівця-ремонтника відіграє наявність відповідних підручників, електронних навчальних програм, тощо високого теоретичного і практичного рівня.

Рівень підготовки фахівця-ремонтника визначається знаннями: об'єкта діагностування, закономірностей зміни його технічного стану і типових несправностей, їх діагностичних параметрів, методів, засобів i діагностичних моделей, алгоритмів діагностування, прогнозування залишкового ресурсу тощо. Рівень таких знань за всіма системами автомобіля визначає кваліфікацію фахівця-ремонтника з діагностики будь-якої BAT.

Разом з цим, з урахуванням того, що Збройні Сили України за останні 7 років отримали на озброєння велику кількість новітніх зразків ВАТ, вже сьогодні існує потреба в створенні новітніх зразків РЗТО та Р. А саме універсальної ремонтно-евакуаційної майстерні ВАТ модульного типу оснащеної сучасними засобами діагностики, контрольно-перевірочними пристроями, спеціальним обладнанням 3 ремонту, обслуговування і евакуації зразків ВАТ на різних рівнях ієрархії у відповідності до обсягів визначених завдань [25]. Така перспектива буде відповідати вимогам теперішнього часу.

Отже, на даний час назріла необхідність у створенні мобільної універсальної ремонтноевакуаційної майстерні (МУР-ЕМ) ВАТ, яка дозволить за допомогою тих самих автомобілів проводити евакуацію й 
переміщення майстерень у нові райони розгортання, об'єднати розрізнені евакуаційні й ремонтні підрозділи в єдиний орган (механізм), який проводить ТО і Р та забезпечує себе ремонтним фондом.

Тобто, в основі формування МУР-ЕМ 3 урахуванням задач, які на неї покладаються щодо відновлення ВАТ в повному обсязі та у встановлені терміни, в рамках яких будуть отримані оціночні чисельні значення показників і критеріїв якості РЗТО та Р для створення мобільної МУР-ЕМ ВАТ в польових умовах, повинні лежати три основних принципи: базовий, мобільний і блочномодульний.

Базовий принцип полягає в розробці базової уніфікованої платформи для сучасних і перспективних зразків вітчизняних виробників, обладнаної вантажнорозвантажувальним механізмом крюкового типу з гідравлічним приводом для швидкої зміни кузовів-контейнерів системи “Мультиліфт" [26]. Вони повинні забезпечувати високу прохідність на місцевості та поєднувати в собі здібності евакуаційних засобів для евакуації несправної або пошкодженої ВАТ.

Мобільний принцип полягає В забезпеченні можливості транспортування РЗОТ та Р різними видами транспорту та у модульному виконанні технологічного обладнання, яке у знятому положенні із шасі колісної платформи дозволяє транспортувати іншими видами транспорту.

Блочно-модульний принцип визначає можливість уніфікації сучасним обладнанням вітчизняного виробника, а саме засобами діагностики, контрольно-перевірочними пристроями, спеціальним обладнанням 3 ремонту та обслуговування. Суть його полягає у визначенні можливостей уніфікації функціональних і технічних властивостей модулів, призначених для вирішення завдань 3 технічного обслуговування та ремонту на різних рівнях ієрархії у відповідності до визначених обсягів завдань з ремонту ВАТ.

Отже із аналізу основних тактикотехнічних характеристик новітньої ВАТ, яка знаходиться на озброєні у військових частинах ЗС України, виникають невідповідності між потребою в проведенні технічного обслуговування та ремонту новітньої ВАТ та можливостями існуючих РЗТО і Р, які знаходяться на озброєнні ремонтно-відновлювальних підрозділів (військових частин) ЗС України. I тут виникає основна проблема, яка полягає в тому, що на більшості зразках ВАТ гарантійний термін завершився або підходить до завершення а існуючі РЗТО та Р ВАТ не адаптовані до проведення зазначених робіт та не укомплектовані відповідними ремонтними комплектами.

\section{Висновки}

Таким чином, на основі тенденції розвитку ВАТ виникає невідповідність між новітньою ВАТ та існуючими на озброєнні ЗС України РЗТО та Р, які не адаптовані до проведення на новітніх зразках ВАТ ТО і Р в польових умовах або під час ведення бойових дій. Вирішуючи завдання в усіх напрямках одночасно, необхідно враховувати як економічні можливості, так і пріоритети в завданнях, які виконуються із застосуванням РЗТО та Р ВАТ на основі яких запропоновано підхід до формування перспективних зразків РЗТО та Р BAT.
Разом з цим, доцільно зробити висновок про необхідність розробки МУР-ЕМ ВАТ, яка б забезпечувала можливість відновлення сучасної ВАТ. Крім того дана майстерня повинна забезпечити виконання основних спеціальних робіт на ВАТ з метою скорочення типів існуючих РЗТО та Р ВАТ.

Створення таких майстерень необхідно орієнтувати на автономне виконання комплексу робіт з технічного обслуговування та ремонту ВАТ від батальйонного рівня ієрархії до стратегічного. Обладнання таких засобів повинне забезпечувати в повному 
обсязі комплекс робіт з відновленню ВАТ, а також виконання найбільш складних операцій під час їх обслуговування в польових умовах та під час ведення бойових дій.

\section{Список використаних джерел}

1. Крайник Л. В., Грубель М. Г. (2018) Проблема оновлення автопарку Збройних Сил України та формування перспективного типажу військової автомобільної техніки в аспекті сучасних тенденцій. Озброєння та військова техніка. 17(1), C. 24-31. DOI: 10.34169/24140651.2018.1(17).24-31.

2. Середенко М. М., Кузьменко Р. В., Хорєв Р. В., Кізло Л. М. (2017) Аналіз форм і способів застосування Сухопутних військ в сучасних умовах, які впливають на розвиток озброєння і військової техніки, засобів технічного забезпечення, підготовки технічних спеціалістів та визначення напрямів їх подальшого вирішення. захист ОВТ від засобів виявлення та ураження, Підготовка військових фахівців. НАСВ імені гетьмана Петра Сагайдачного, м. Львів, 16, С. 65-71. URL: http://vtz.asv.gov.ua/article/view/149286/1 48447

3. Пат. 89968 Україна, МПК' (2009) F 41 Н 7/02. Легка броньована колісна машина / Купрієнко О. М., Лапицький С. В., Голуб В. А., Бісик С. П., Ларін О. Ю., Чеченкова О. Л.; заявник і володар патенту Купрієнко О. М.. - № u201312968; заяв. 8.11.2013; опубл. 12.05.2014, Бюл. № 9.

4. Лапшин Ф. (2013) Броневахтовики. Авторевю - Украина. Київ: Авторевю, С. 55-60.

5. Капранов М. Ю., Шевченко А. В., Лукянов А. В., Соколенко В. Н. (2010) Современная бронетанковая техника армий иностранных государств. Кубинка: ЗАО “Компания ИМАДЖВЕЙН", С. 394.

6. Дачковський В. О., Овчаренко І. В (2016) Аналіз розвитку бойових броньованих машин. Сучасні інформачійні технології у срері безпеки та оборони. НУОУ, М. Київ, № 2(26). С. 127-131.

7. Зеленковский В. В., Каптюх А. Н., Мороз А.
Ф. (2018) Требования к создаваемым образцам вооружения, военной и специальной техники. Научный вестник Вольского военного института материального обеспечения. №4 (48), С. 47-52.

8. Соболев Е. Г. (2012) Методические аспекты комплексной оценки эксплутационнотехнических свойств объектов ВВТ. Стратегчческая стабильность. №4(61). C. 59-66.

9. Тарасенко П. Н., Цыганков В. Н. (2009) Перспективные подвижные средства восстановления вооружения и военной техники. Новости науки и технологий. № 2 (11). С. 26-32.

10. Шишанов М. О., Гуляєв А. В., Зубарєв О. В., Шевцов М. М. (2017) Методологія обґрунтування тактико-технічних вимог до технічних засобів відновлення. Озброєння та військова техніка. ЦНДІ ОВТ, М. Київ, 2(14), C. 80-83.

11. Старцев В. В., Рогозін І. В., Литовченко Д. М. (2016) Перспективи створення сучасної рухомої автомобільної ремонтної майстерні вітчизняного виробництва. Системи озброєння і військова техніка. ХНУПС ім. І. Кожедуба, м. Харків, № 2(46). C. 150-154.

12. Лисий М., Мисик А., Дачковський В., Горбачова Я. (2019) Напрямки розвитку озброєння та військової техніки щодо підвищення рівня захищеності. Збірник наукових праць Національної академії Державної прикордонної служби України Серія: військові та технічні науки. м. Хмельницький, № 3(87). С. 411-428.

13. Пат. 122446 Україна, МПК (2009) F41 H 7/00. Базова гусенична платформа модульного типу / Дачковський В. О., Овчаренко І. В., Ярошенко О. В., Сампір О. М., Куровська Т. Ю. - заявник і володар патенту Дачковський В.О. - № a201812481; 
заяв. 17.12.2018; опубл. 10.11.2020; Бюл. № 21/2020.

14. Пат. 134972 Україна, МПК (2009) ) F41 H 7/00. Базова колісна платформа модульного типу / Дачковський В.О. заявник і володар патенту Дачковський B.O. - № u2019 00225; заяв. 09.01.2019; опубл. 10.06.2019; Бюл. № 11/2019.

15. Українські військові сторінки (Ukrainian Military Pages) URL: https://www. ukrmilitary. com/2015/04/hmmwv. html

16. Військовий сектор автомобілі КрАЗ спеціального призначення. URL: http://www.autokraz.com.ua/index.php/ru/ fabrication/automobile/military.

17. ООО “Верхнеднепровский Авторемонтный Завод" URL: http://varz.dp.ua/ products.

18. Корпорація Богдан, виробництво, військова техніка URL: https://bogdan.ua/ strukturakorporatsiyi/vyrobnytstvo/ vijskova-tehnika

19. Українські військові сторінки (Ukrainian Military Pages) URL: https://www.ukrmilitary.com/2015/10/koza k-2-2015.html.

20. Українські військові сторінки (Ukrainian Military Pages) URL: https://www.ukrmilitary.com/2017/08/arm ored-bogdan-maz-6317-multilift.html.

21. Конструкторське-виробниче підприємством “Українська бронетехніка" URL: https://ukrarmor.com/uk/typeproducts/spetsi alizovani-bronovani-avtomobili/.

22. Дачковський В. О., Родченко Л. М. (2019) Методика оцінювання відновлюваності озброєння та військової техніки Сучасні інформаційні технології у сфрері безпеки та оборони. НУОУ, м. Київ, № 3(36), С. 8996.

23. Dachkovskyi, V. (2020). Methodology of explanation of tactical and technical requirements for means of evacuation of weapons and military equipment. Journal of Scientific Papers "Social Development and Security», 10(3), 104-113. DOI: 10.33445/sds.2020.10.3.9

24. Мигаль В. Д. (2016) Основы технической диагностики автомобилей. учебное пособие. - 2-е изд., переработанное и дополненное. ХНАДУ: Майдан,. С. 7, С. 256259.

25. Dachkovskyi, V. (2019). Methodology of justification of tactical and technical requirements for movable means of repairing arms and military equipment. Journal of Scientific Papers "Social Development and Security», 9(6), 86-101. DOI: 10.33445/sds.2019.9.6.7

26. Международная выставка вооружения и военной техники “Milex - 2007" [Електронний ресурc]: URL: https://www.vpk.gov.by/activity/event/mile $\mathrm{x}$-2007.html.

\section{Анализ парка военной автомобильной техники, которая потребует восстановления подвижными средствами технического обслуживания и ремонта}

\footnotetext{
Владимир Дачковский * А; Игорь Кондратюк ${ }^{\text {A }}$

*Corresponding author: к.т.н., доцент, доцент кафедры, e-mail: 1903vova@ukr.net, ORCID: 0000-0003-1480-5021

А Национальный университет обороны Украины имени Ивана Черняховского, пр-кт Воздухофлотский, 28, г. Киев, 03049, Украина
}

\section{Аннотация}

В статье проведен анализ парка военной автомобильной техники воинских частях Вооруженных Сил Украины, которая находится на вооружении воинских частей (подразделений) Вооруженных Сил Украины и которая потребует технического обслуживания и ремонта подвижными средствами технического обслуживания и ремонта в полевых условиях во время ведения боевых действий. Проведенный анализ военной автомобильной 
техники свидетельствует, что большинство новейших образцов, находящихся на вооружении в воинских частях Вооруженных Сил Украины, находятся на гарантийном сроке эксплуатации от производителя, который подходит к завершению или уже завершился. По результатам анализа установлено, что большинство образцов автомобильной техники оснащены новейшими базовыми шасси зарубежных производителей, дизельными двигателями экологического класса Евро IV, современными системами обеспечения, электрооборудованием и контрольно-измерительными приборами нового поколения. Вместе с тем, проведенный анализ основных неисправностей новейших образцов военной автомобильной техники показал, что образцы военной автомобильной техники в основном выходили из строя из-за низкого качества отдельных деталей и сборочных единиц, неудовлетворительное состояние сырья или нарушения технологического процесса. Кроме того, учитывая потребность в проведении технического обслуживания и ремонта военной автомобильной техники определены несоответствия в возможностях существующих на вооружении подвижных средств восстановления. Определено, что в основе формирования подвижных средств технического обслуживания и ремонта с учетом задач возлагаемых на ремонтно-восстановительные подразделения должны лежать три основных принципа: базовый, который заключается в разработке унифицированной базовой платформы; мобильный, который заключается в обеспечении возможности транспортировки различными видами транспорта; блочно-модульный, который заключается в комплектовании современными средствами диагностики и специальным оборудованием для выполнения специфическими задач по техническому обслуживанию и ремонту военной автомобильной техники на различных уровнях иерархии.

Ключевые слова: военная автомобильная техника, подвижные средства технического обслуживания и ремонта, восстановление, техническое обслуживание и ремонт.

\title{
Analysis of the fleet of military vehicles that will need to be restored by rolling stock maintenance and repair
}

\author{
Vladimir Dachkovsky * A; Igor Kondratiuk ${ }^{\text {A }}$ \\ ${ }^{*}$ Corresponding author: Candidate of Technical Sciences, Associate Professor, Associate Professor of the Department, e-mail: 1903vova@ukr.net, \\ ORCID: 0000-0003-1480-5021 \\ A National Defence University of Ukraine named Ivan Chernyaiskhovskyi, 28 Povitroflotsky Ave., Kyiv, 03049, Ukraine
}

\begin{abstract}
The article analyzes the fleet of military vehicles of the military units of the Armed Forces of Ukraine, which is in service with military units (divisions) of the Armed Forces of Ukraine and which will require maintenance and repair by mobile means of maintenance and repair in the field during hostilities. An analysis of military vehicles shows that most of the latest models in service in the military units of the Armed Forces of Ukraine are under warranty from a manufacturer that is nearing completion or has already been completed. According to the results of the analysis, it is established that most models of automotive equipment are equipped with the latest basic chassis of foreign manufacturers, diesel engines of ecological class Euro IV, modern supply systems, electrical equipment and control and measuring devices of the new generation. At the same time, the analysis of the main malfunctions of the latest models of military vehicles showed that the samples of military vehicles mainly failed due to low quality of individual parts and components, unsatisfactory condition of raw materials or technological process violations and so on. In addition, taking into account the need for maintenance and repair of military vehicles, inconsistencies in the capabilities of existing weapons of recovery have been identified. It is determined that the basis for the formation of mobile means of maintenance and repair, taking into account the tasks assigned to the repair and restoration units should be three main principles: basic, which is to develop a unified basic platform; mobile,
\end{abstract}


which consists in providing the possibility of transportation by different modes of transport; block-modular, which consists in the acquisition of modern diagnostic tools and special equipment to perform specific tasks for maintenance and repair of military vehicles at different levels of the hierarchy.

Keywords: military vehicles, mobile maintenance and repair, restoration, maintenance and repair.

\section{References}

1. Kraynyk L. V., Hrubel' M. H. (2018) Problema onovlennya avtoparku Zbroynykh Syl Ukrayiny ta formuvannya perspektyvnoho typazhu viys'kovoyi avtomobil'noyi tekhniky $\checkmark$ aspekti suchasnykh tendentsiy. Ozbroyennya ta viys'kova tekhnika. Kiiv, Ukraine, 17(1), S. 24-31. DOI: 10.34169/2414-0651.2018.1(17).24-31.

2. Seredenko M.M., Kuz'menko R.V., Khoryev R.V., Kizlo L.M. (2017) Analiz form i sposobiv zastosuvannya Sukhoputnykh viys'k v suchasnykh umovakh, yaki vplyvayut' na rozvytok ozbroyennya i viys'kovoyi tekhniky, zasobiv tekhnichnoho zabezpechennya, pidhotovky tekhnichnykh spetsialistiv ta vyznachennya napryamiv yikh podal'shoho vyrishennya. Zakhyst OVT vid zasobiv vyyavlennya ta urazhennya, Pidhotovka viys'kovykh fakhivtsiv. NASV imeni het'mana Petra Sahaydachnoho, m. L'viv, 16, S. 65-71. Rezhym dostupu: http://vtz.asv.gov.ua/article/view/149286/1 484473.

3. Pat. 89968 Ukrayina, MPK' (2009) F 41 N 7/02. Lehka bron'ovana kolisna mashyna / Kupriyenko O.M., Lapyts'kyy S.V., Holub V.A., Bisyk S.P., Larin O.YU., Chechenkova O.L.; zayavnyk i volodar patentu Kupriyenko O.M.. - № u201312968; zayav. 8.11.2013; opubl. 12.05.2014, Byul. № 9 .

4. Lapshyn F. (2013) Bronevakhtovyky. Avtorevyu - Ukrayna. - Kyiv: Avtorevyu, S. 55-60.

5. Kapranov M.YU., Shevchenko A.V., Lukyanov A.V., Sokolenko V.N. (2010) Sovremennaya bronetankovaya tekhnyka armyy ynostrannykh hosudarstv. Kubynka: ZAO "Kompanyya YMADZHVEYN", S.3 94.
6. Dachkovs'kiy V.O., Ovcharenko Í.V (2016) Analíz rozvitku boyovikh bron'ovanikh mashin. Suchasní ínformatsíyní tekhnologiï u sferi bezpeki ta oboroni. NUOU, m. Kyiv, №2(26) S. 127 - 131.

7. Zelenkovskiy V.V., Kaptyukh A.N., Moroz A.F. (2018) Trebovaniya k sozdavayemym obraztsam vooruzheniya, voyennoy i spetsial'noy tekhniki. Nauchnyy vestnik Vol'skogo voyennogo instituta material'nogo obespecheniya. №4 (48), S. 47-52.

8. Sobolev Ye.G. (2012) Metodicheskiye aspekty kompleksnoy otsenki eksplutatsionnotekhnicheskikh svoystv ob'yektov VVT. Strategicheskaya stabil'nost'. №4(61) S. 5966.

9. Tarasenko P.N., Tsygankov V.N. (2009) Perspektivnyye podvizhnyye sredstva vosstanovleniya vooruzheniya i voyennoy tekhniki. Novosti nauki i tekhnologiy. № 2 (11) s. 26-32.

10. Shyshanov M.O., Hulyayev A.V., Zubaryev O.V., Shevtsov M.M. (2017) Metodolohiya obgruntuvannya taktyko-tekhnichnykh vymoh do tekhnichnykh zasobiv vidnovlennya. Ozbroyennya ta viys'kova tekhnika. TSNDI OVT, m. Kyiv, 2(14), S. 80-83.

11. Startsev V.V., Rohozin I.V., Lytovchenko D.M. (2016) Perspektyvy stvorennya suchasnoyi rukhomoyi avtomobil'noyi remontnoyi maysterni vitchyznyanoho vyrobnytstva. Systemy ozbroyennya $i$ viys'kova tekhnika. KHNUPS im. I. Kozheduba, m. Kharkiv, №2(46). S. 150-154.

12. Lysyy M., Mysyk A., Dachkovs'kyy V., Horbachova YA. (2019) Napryamky rozvytku ozbroyennya ta viys'kovoyi tekhniky shchodo pidvyshchennya rivnya zakhyshchenosti. Zbirnyk naukovykh prats' Natsional'noyi 
akademiyi Derzhavnoyi prykordonnoyi sluzhby Ukrayiny Seriya: viys'kovi ta tekhnichni nauky. m. Khmel'nyts'kyy, № 3(87). S. 411-428.

13. Pat. 122446 Ukrayina, MPK (2009) ) F41 H 7/00. Bazova husenychna platforma modul'noho typu / Dachkovs'kyy V.O., Ovcharenko I.V., Yaroshenko O.V., Sampir O.M., Kurovs'ka T.YU. - zayavnyk i volodar patentu Dachkovs'kyy V.O. - № a201812481; zayav. 17.12.2018; opubl. 10.11.2020; Byul. № $21 / 2020$.

14. Pat. 134972 Ukrayina, MPK (2009) ) F41 H 7/00. Bazova kolisna platforma modul'noho typu / Dachkovs'kyy V.O. - zayavnyk i volodar patentu Dachkovs'kyy V.O. - № u2019 00225; zayav. 09.01.2019; opubl. 10.06.2019; Byul. № 11/2019.

15. Ukrayins'ki viys'kovi storinky (Ukrainian Military Pages). Rezhym dostupu: https:// www.ukrmilitary.com/2015/04/hmmwv.htm I.

16. Viys'kovyy sektor avtomobili KrAZ spetsial'noho pryznachennya. Rezhym dostupu:

http://www.autokraz.com.ua/index.php/ru/ fabrication/automobile/military.

17. 000 «Verkhnedneprovskyy Avtoremontnyy Zavod». Rezhym dostupu: (http://varz.dp.ua/products).

18. Korporatsiya Bohdan, vyrobnytstvo, viys'kova tekhnika. Rezhym dostupu: https://bogdan.ua/struktura korporatsiyi/ vyrobnytstvo/vijskova-tehnika.

19. Ukrayins'ki viys'kovi storinky (Ukrainian Military Pages) - Rezhym dostupu: https://www.ukrmilitary.com/2015/10/koza k-2-2015.html.
20. Ukrayins'ki viys'kovi storinky (Ukrainian Military Pages). Rezhym dostupu: https://www.ukrmilitary.com/2017/08/arm ored-bogdan-maz-6317-multilift.html.

21. Konstruktors'ko-vyrobnyche pidpryyemstvom "Ukrayins'ka bronetekhnika". Rezhym dostupu: https://ukrarmor.com/uk/typeproducts/spe tsializovani-bronovani-avtomobili/.

22. Dachkovs'kyy V.O., Rodchenko L.M. (2019) Metodyka otsinyuvannya vidnovlyuvanosti ozbroyennya ta viys'kovoyi tekhniky. Suchasni informatsiyni tekhnolohiyi u sferi bezpeky ta oborony. NUOU, m. Kyyiv, № 3(36), S. 89-96.

23. Dachkovskyi , V. (2020). Methodology of explanation of tactical and technical requirements for means of evacuation of weapons and military equipment. Journal of Scientific Papers "Social Development and Security», 10(3), 104-113. DOI: 10.33445/sds.2020.10.3.9

24. Myhal' V. D. (2016) Osnovy tekhnycheskoy dyahnostyky avtomobyley. Uchebnoe posobye. - 2-e yzd., pererabotannoe y dopolnennoe. XNADU: Maydan,. s. 7, s. 256259.

25. Dachkovskyi, V. (2019). Methodology of justification of tactical and technical requirements for movable means of repairing arms and military equipment. Journal of Scientific Papers "Social Development and Security", 9(6), 86-101. DOI: 10.33445/sds.2019.9.6.7

26. Mezhdunarodnaya vystavka vooruzhenyya y voennoy tekhnyky "Milex - 2007" [Elektronnyy resurs]: Rezhym dostupu: https://www.vpk.gov.by/activity/event/mile x-2007.html. 